\title{
Wspomnienie o prof. Stanisławie Jaworskim
}

ABSTRACT. Burzyńska Anna, Wspomnienie o prof. Stanisławie Jaworskim [In Memory of Professor Stanisław Jaworski]. „Przestrzenie Teorii” 29. Poznań 2018, Adam Mickiewicz University Press, pp. 383-386. ISSN 1644-6763. DOI 10.14746/pt.2018.29.18.

Professor Stanisław Jaworski, the prominent literary theoretician and historian, literary critic, poet, worker of the Faculty of Polish Studies at the Jagiellonian University and the long-time member of the editorial board and editor-in-chief of "Ruch Literacki" died on 15th July 2018.

KEYWORDS: literary study, theory of literature, history of literature, avant-garde, literary criticism, poetry

15 lutego 2018 roku zmarł prof. dr hab. Stanisław Jaworski, wybitny teoretyk i historyk literatury, krytyk literacki i poeta, profesor na Wydziale Polonistyki Uniwersytetu Jagiellońskiego, wieloletni członek redakcji i redaktor naczelny „Ruchu Literackiego”.

Profesor Stanisław Jaworski urodził się 12 września 1934 roku w Częstochowie, ale to z Krakowem i z Uniwersytetem Jagiellońskim połączył całe swoje dojrzałe życie. Studiował polonistykę na krakowskiej Alma Mater, a następnie związał się z nią zawodowo. Był znakomitym pedagogiem i świetnym wykładowca - równie kompetentnym (co rzadkie) historykiem, jak i teoretykiem literatury. Wykształcił wiele pokoleń polonistów, wypromował ogromną liczbę licencjatów, magistrów i doktorów, uczestniczył w wielu przewodach habilitacyjnych i procedurach awansowych. Pełnił też na uczelni ważne i prestiżowe funkcje - prodziekana Wydziału Filologicznego (1975-1978), dziekana tegoż Wydziału (1978-1981), wicedyrektora Instytutu Filologii Polskiej (1984-1988) oraz kierownika Zakładu (później Katedry) Teorii Literatury i Poetyki Historycznej (1976-1979, 1993-1996). Godnie reprezentował też uczelnię za granica - prowadząc zajęcia z języka i literatury polskiej w Grenoble, Nancy i Lyonie. Francja była niewątpliwie jego druga duchowa ojczyzna, czuł się tam znakomicie i był też wybitnym znawca literatury francuskiej, zwłaszcza Awangardy. Znakomicie władał językiem francuskim, był też obyty z francuską i europejską kulturą duchowa, a ten niepowtarzalny klimat wnosił w mury krakowskiej uczelni. W późniejszym okresie życia - w latach 1998-2014 - związał się też zawodowo z Tarnowem, gdzie został nauczycielem akademickim w Zakładzie Filologii Polskiej Państwowej Wyższej Szkoły Zawodowej. Prowadził tam wykłady z zakresu poetyki i teorii literatury oraz literatury współczesnej. 
Był promotorem wielu prac dyplomowych studentów studiów licencjackich i magisterskich na filologii polskiej. W latach 2009-2014 pełnił też funkcję kierownika zespołu naukowego literatury współczesnej i teorii literatury w Zakładzie Filologii Polskiej PWSZ. Stał się w tarnowskiej szkole postacią wręcz kultowa - tam również wywarł ogromny wpływ na liczne rzesze uczniów i pracowników.

Profesor Jaworski przez bardzo wiele lat pracował też w redakcji „Ruchu Literackiego" - najpierw jako członek redakcji, a następnie jako wieloletni redaktor naczelny. Poświęcał temu pismu wiele czasu i energii, bez wątpienia również w znaczący sposób przyczynił się do jego znakomitego poziomu naukowego. $\mathrm{Z}$ wielka rozwagą i wyczuciem aktualnie ważnych tematów dobierał artykuły do kolejnych numerów i publikował w nim swoje własne teksty.

Wreszcie - nie tylko zajmował się literatura naukowo, ale był także jej praktykiem - poeta. Począwszy od debiutu poetyckiego w 1955 roku na łamach „Dziennika Polskiego”, pisał i publikował wiersze aż do śmierci także w innych czasopismach (np. w „Życiu Literackim”, „Poglądach” czy „Zebrze”). W latach 1956-1958 był też członkiem redakcji „Zebry”. Jako twórca literatury potrafił rozbudzać pasję pisania zwłaszcza w młodych, wrażliwych ludziach, których nierzadko otaczał troskliwą opieka, pielęgnując ich talent i udzielając im wielu cennych uwag. Swoim doświadczeniem i artystycznymi inspiracjami dzielił się również, prowadząc przez wiele lat zajęcia z adeptami literatury w Studium Literacko-Artystycznym Uniwersytetu Jagiellońskiego. Jako autentyczny pasjonat i miłośnik poezji wpływał nie tylko na sferę intelektu, lecz też na emocje, rozniecał apetyt na poezję.

W dorobku naukowym Profesora Jaworskiego znalazło się wiele intersujących i ważnych rozpraw naukowych i książek - począwszy od tych poświęconych Tadeuszowi Peiperowi oraz awangardzie (U podstaw awangardy, Między awangarda i nadrealizmem, Odnajdywanie świata), poprzez edycję dzieł lidera Awangardy Krakowskiej, następnie wnikliwe analizy zawiłości procesu twórczego (Piszę, więc jestem), omówienia specyfiki literatury współczesnej (Zakręty i przełomy: studia o literaturze XX wieku), porządkowanie terminologii literaturoznawczej i periodyzacje literackie (kolejne Stowniki terminów literackich), aż do ostatnio wydanej książki Maski, gesty, słowa poświęconej rozmaitym sposobom przejawiania się ,ja” poetyckiego, a nawet wkraczającej w specyfikę zagadnień literackiej autoprezentacji internetowej, co świadczyło o tym, że nie tylko wspaniale orientuje się w literackiej przeszłości czy niedawnej współczesności, ale też nieobce są mu najświeższe nowinki i najnowsze trendy. Fascynowała go przede wszystkim polska i zagraniczna (zwłaszcza francuska) awangarda literacka i znał się na niej 
jak nikt. Jego prace dotyczące twórczości awangardowej były pionierskie i odkrywcze, po dziś dzień tworzą one kanon podstawowej wiedzy na ten temat i stanowią cenne źródło informacji dla wszystkich zajmujących się tą problematyka. Mimo zawansowanego wieku Stanisław Jaworski do samego końca zachowywał świetną sprawność intelektualną, odznaczał się znakomitą pamięcia, przebogatą i wszechstronną erudycja, a także wszelkimi innymi kompetencjami potrzebnymi badaczowi literatury.

Po osiagnięciu wieku emerytalnego Profesor Jaworski nie ograniczył aktywności naukowej i udziału w życiu uczelni. Wprost przeciwnie - zawsze był obecny. Zajmował swoje stałe miejsce na Radach Wydziału Polonistyki Uniwersytetu Jagiellońskiego, regularnie przychodził na zebrania Katedry Teorii Literatury, do końca aktywnie uczestniczył w pracach Uniwersytetu Jagiellońskiego i innych placówek badawczych w Polsce oraz za granicą. Do samego końca spotykał się też z licznym gronem swoich uczniów, czuwał nad nimi - niezależnie od wieku i pozycji zawodowej. Nieprzerwanie też inspirował ich i pobudzał do myślenia.

Bardzo trudno mówić o Profesorze w czasie przeszłym, bo wszyscy cenili jego dorobek naukowy, ale też, tak zwyczajnie i po ludzku, go lubili. Profesor był pięknym człowiekiem w pełnym tego słowa znaczeniu - niekonfliktowym, życzliwym, ciepłym, zdystansowanym do siebie i świata. Emanował spokojem i delikatnościa, roztaczał wokół siebie trochę staroświecki urok. Odznaczał się niezwykłą kulturą osobistą i łagodnością - sprawiało to, że w jego towarzystwie wszyscy - od studenta po profesora - czuli się bezpiecznie. Miał specyficzne, subtelne poczucie humoru, umiał znakomicie opowiadać, znał wiele ciekawostek i anegdot, co sprawiało, że każde spotkanie z nim - nawet krótka rozmowa na korytarzu - było zawsze znaczące i zapisywało się w pamięci. Nigdy nie zabiegał o rozgłos i nie starał się zrobić kariery za wszelką cenę. Był - zwłaszcza dzisiaj - nieczęsto spotykanym przykładem człowieka i uczonego, który osiagnał tak wiele bez nachalnej autoprezentacji, narcyzmu i rozpychania się łokciami. Mimo to tak bardzo wrósł w środowisko Uniwersytetu Jagiellońskiego, był tak znaczącą postacią polskiej i zagranicznej humanistyki, iż zapewne nikt nie wyobrażał sobie, że kiedyś może go zabraknaćc.

Wielu jego uczniów - w tym piszacca te słowa - uważa go za prawdziwego Mistrza i człowieka charyzmatycznego, na swój własny, nieoczywisty sposób. Szczególną rolę odegrał Profesor w dawnych, komunistycznych latach, co bardzo dobrze pamiętam, bo byłam wówczas jego studentka. Z tamtego okresu szczególnie mocno zapisał mi się w pamięci niezwykle smutny moment śmierci kolegi ze studiów - Stanisława Pyjasa. Byłam wtedy na pierwszym roku studiów i bardzo mocno to przeżyłam. Przerażający był nie tylko sam fakt, ale również zmowa milczenia, która mu towarzyszyła. Profesor Jawor- 
ski - ówczesny prodziekan Wydziału Filologicznego - umożliwił wówczas studentom udział w pogrzebie, załatwił nawet autobusy, które dowiozły ich na uroczystość pogrzebowa. Z dzisiejszego punktu widzenia może się wydawać, że to niewiele, ale wtedy był to akt wielkiej odwagi, grożacy poważnymi sankcjami. Taki właśnie był Pan Profesor - człowiek spokojny i cichy, ale uczciwy i odważny, zawsze postępujący w zgodzie z własnym sumieniem. Wówczas też, zwłaszcza młodzi adepci, teorii literatury czuli się okropnie - odcięci od wszystkiego tego, co w tej dyscyplinie działo się w Europie czy na świecie. Stanisław Jaworski doskonale się w tym w tym wszystkim orientował, był dla nas prawdziwym emisariuszem wiedzy niedostępnej dla ogółu, a przez to niezwykle fascynujacej. Dzieląc się nia, obdarzał nas dawkami intelektualnej wolności, której tak bardzo nam wtedy brakowało - opowiadał o Rolandzie Barthesie, Jacques’ie Derridzie, Julii Kristevej, Philippie Sollersie, o nouveau roman i nouvelle critique. A przekazywał tę wiedzę lekko, niemal mimochodem, zawsze jakby trochę zakłopotany tym, że nad nami góruje. Jego łagodność mobilizowała do poszukiwań i przemyśleń znacznie bardziej niż jakiekolwiek środki nacisku. Otaczając opieką bardziej już zaawansowane projekty naukowe, zawsze sprawiał, że adept czuł się partnerem, że rozwijał się w pełnym tego słowa znaczeniu. Całą swoją postawa Profesor dawał do zrozumienia, że sposób przekazywania wiedzy jest tak samo ważny, a nierzadko nawet ważniejszy, niż sama wiedza. Że z młodymi, często bardzo wrażliwymi ludźmi, jacy przychodzą na Wydział Polonistyki, należy postępować tak, by ich nie stłamsić i nie zniszczyć tego, co w nich najcenniejsze. Podobnie zachowywał się w kontaktach z koleżankami i kolegami z Wydziału - każdemu okazywał szacunek. Na zebraniach Katedry Teorii Literatury do samego końca zaskakiwał nas nieoczekiwanymi skojarzeniami, trafnymi uwagami, wnikliwymi komentarzami. Widać było, że nawet jeśli niekoniecznie aprobuje wszystkie te dziwaczne rzeczy, którymi zajmuja się teraz zwłaszcza najmłodsi badacze literatury, to jednak nieustannie trzyma rękę na pulsie i - co nie mniej ważne - potrafi uszanować inny punkt widzenia.

Profesor Jaworski w znaczący sposób wpłynął na wielu literaturoznawców, ukształtował ich mentalnie i psychicznie. Własnym przykładem udowadniał, że nie potrzeba robić wokół siebie wielkiego hałasu, by zapisać się piękną kartą w umysłach i sercach uczniów i współpracowników, że nie trzeba naciskać, by osiagnąć spodziewany efekt, że subtelnością i delikatnością można zdziałać o wiele więcej, niż podniesionym głosem. Że można mocno zaznaczyć swój ślad, czyniąc to w niemal niedostrzegalny sposób. Będzie nam go bardzo brakowało! 